\title{
El retrato de Maldoror a la luz del livre d'artiste surrealista (1934-1948)
}

\author{
Iván Moure Pazos \\ Istituto di Studi Superiori. Universita di Bologna. \\ ivan.menes@yahoo.es
}

Recibido: 17-05-2012

Aceptado: 15-10-2012

\section{RESUMEN}

Maldoror es un personaje mutable. No existe una representación canónica de su figura, y ésta se descuella en informes transmutaciones y metamorfosis. Poner límites a tal entelequia, ha sido uno de los juegos preferidos de los surrealistas mediante los llamados livres d'artiste. El presente artículo, trata de ser una antología de la original retratística maldororiana a través de las diferentes ediciones de Les Chants de Maldoror del Conde de Lautréamont sucedidas entre 1934 y 1948.

Palabras clave: Maldoror, Conde de Lautréamont, Surrealismo, Livre d'artiste, Les Chants de Maldoror.

\section{Maldoror's Portrait throught the Surrealist Livre d'Artiste (1934-1948)}

\begin{abstract}
Maldoror is a mutable character. There is no canonical representation of his figure, and it gets threshed in formless transmutation and metamorphosis. Put limits to this entelechy, has been one of the favorite games for the surrealists through the so-called livres d'artiste. This article tries to be an anthology of the creative maldororian portraiture through different editions of Lautréamont Count's Les Chants de Maldoror, wich took place between 1934 and 1948.
\end{abstract}

Key words: Maldoror, Lautréamont Count, Surrealism, Artist's book, The songs of Maldor.

Sumario: Introducción. 1. El cruce de disciplinas. 2. Los retratos de Maldoror. 3. Conclusiones. 


\section{Introducción}

Actualmente, el surrealismo puede presumir de ser uno de los movimientos artísticos más longevos del siglo XX. Su fecha de defunción nunca fue sentenciada, simplemente olvidada. Incluso ha sobrevivido al deceso pronosticado por la crítica anglonorteamericana tras la segunda guerra mundial. Por entonces, Nueva York relevaba a París como capital artística, y con ello, la larga hegemonía de la intelectualidad francesa comenzaba a decaer. Era el tiempo del expresionismo abstracto y de los grandes teóricos norteamericanos ${ }^{1}$. La vanguardia europea se perdería entre las nuevas propuestas que asolaban el viejo continente desde el otro extremo Atlántico. Sobre ello específica Hal Foster:

"Para los neovanguardistas que cuestionaban el relato formalista durante los años 50 y 60, el surrealismo aparecía además, como corrupto: con un aspecto Kitsch en términos de sus técnicas, filosóficamente subjetivo e hipócritamente elitista"².

Entretanto, en Europa, el superrealismo resistía a las neovanguardias (minimalismo, pop-art), gracias a la labor de intelectuales europeos como Juan Eduardo Cirlot o André Bretón, vinculados íntimamente al movimiento originario ${ }^{3}$.

Sin embargo, era de esperar una pronta relectura. En los ochenta los grandes historiadores del arte norteamericanos comenzaron a teorizar sobre el surrealismo, promovidos en gran parte por las nuevas temáticas de género (colectivos de gays y lesbianas), que se ampararon en la representatividad sexual de Breton y afines como antecedente directo de sus propuestas. The optical Unconscius (1993) de Rosalind. E. Krauss o la Compulsive Beauty (1993) de su discípulo Hal Foster, contribuirán al asentamiento definitivo de un movimiento hasta entonces denostado. El hiperrealismo volvía a estar en el punto de mira del panorama artístico internacional. De nuevo los archivos de la gran biblioteca francesa eran desempolvados. Había nacido el neosurrealismo. En estos escritos, las menciones al Conde de Lautréamont -pseudónimo de Isidore Ducasse- a Les Chants de Maldoror (1868), así como a su antihéroe Maldodor, serán frecuentes. Sin ánimo de dilatarnos en esta prolífica bibliografía, reseñamos en nota las páginas de libros que tratan sobre esta correspondencia ${ }^{4}$. El universo

1 Verdad que también en América existió un grupo surrealista, pero tardío y manifiestamente marginal. Vid. VV. AA., ¿Qué hay de nuevo viejo? Textos y declaraciones del Movimiento Surrealista de los Estados Unidos (1967-1999), Logroño, Pepitas de calabaza, 2008.

2 FOSTER, Hal, Belleza compulsiva, Buenos Aires, Adriana Hidalgo Editora, 2008, p. 11.

3 Para una mejor comprensión del surrealismo tardío consultar, MAHON, Alice, Surrealismo, Eros y Política, 1938-1968, Madrid, Alianza, 2009.

4 Por orden cronológico se resaltan las siguientes páginas de libros: BRETON, André, "Introduction" en Lautréamont, Comte de, Oeuvres Completes, Paris, G.M.L., 1938, pp. 9-15; RUBIN, Willian, Dada and Surrealist Art, New York, Abrams, 1969, p. 62; TORCZYNER, Harry, Magritte. Signos e imágenes, Barcelona, Blume, 1978, pp. 9-20; FORNÉS, Eduard, Dali y los libros, Barcelona, Caja de Barcelona, 1985, p. 91; ROJAS, Carlos, El mundo mítico y mágico de Salvador Dalí, Barcelona, Plaza y Janés, 1985, pp. 234-258; HUBERT, Renée Riese, Surrealism and the book, Berkeley, University of California Press, 1988, pp. 205-209; SÁNCHEZ VIDAL, Agustín, Buñuel, Lorca, Dalí: el enigma sin fin, Barcelona, Planeta, 1988, pp. 281-285; GABLIK, Suzi, Magritte, London, Thames and Hudson, 1992, pp. 44-48; DESCHARNES, Robert., NÉRET, Gilles, La obra pictórica, Colonia, Benedikt Taschen, 1993, p. 211; DUPIN, Jacques, Miró, Barcelona, Polígrafa, 1993, pp. 200-202; KRAUSS, Rosalind, El inconsciente óptico, Madrid, Tecnos, 1993, 
lautreamontiano, se convertirá en una de las fuentes primordiales del repertorio iconográfico surrealista. De todos modos, cabe aclarar, que el tributo hiperrealista para con el Conde se consideró excesivamente críptico. ¿Por qué? Hasta bien entrado el siglo XX, el paralelismo semántico y estructural entre texto e imagen obedecía a unas normas de correspondencia sígnica inquebrantables ${ }^{5}$. Los surrealista -inspirados por Lautréamont- buscaron la alteración de ese estatuto semántico. Para ello, se sirvieron de múltiples contaminaciones iconográficas, nutridas de vivencias personales y una amplia gama de documentos hipercodificados vinculados a la emblemática lautrea-

p. 55; CIRLOT, Juan Eduardo, Diccionario de los símbolos, Barcelona, Ediciones Siruela, 1997, p. 342; GIBSON, Ian, La vida desaforada de Salvador Dalí, Barcelona, Anagrama, 1997, pp. 398-405; del mismo autor, Lorca-Dalí. El amor que no pudo ser, Barcelona, Plaza y Janés, 1999, pp. 125-126; RAINWATER, Robert, "Au rendez-vous des amis: Surrealist Books and the Beginning of Surrealist Printmaking" in VV. AA., Visionary States: Surrealist Prints from the Gilbert Kaplan Collection, Los Angeles, University of California, 1997, p. 26; KRAUSS, Rosalind, Lo fotográfico, Barcelona, Gustavo Gili, 2002, p. 174; BRETON, André, Manifiestos del surrealismo, Madrid, Losada, 2002, p. 114; RAMÍREZ, Juan Antonio, Dali: lo crudo y lo podrido, Madrid, Antonio Machado Libros, 2002, p. 60; ADES, Dawn, Fotomontaje, Barcelona, Gustavo Gili, 2002, p. 115; FANÉS, Fèlix, "Prólogo" en Dalí, Salvador, Obra Completa de Salvador Dalí, Vol. I, Barcelona, Destino, Fundación Gala-Salvador Dalí, Sociedad Estatal de Conmemoraciones Culturales, 2003, pp. 2931; SÁNCHEZ VIDAL, Agustín, "Introducción" en Dalí, Salvador, Obra Completa de Salvador Dalí, Vol. III, Barcelona, Destino, Fundación Gala-Salvador Dalí, Sociedad Estatal de Conmemoraciones Culturales, 2003, pp. 31-38; el anónimo, H.H., "Les Chants de Maldodor", en VV. AA., Catálogo de la exposición Dali, celebrada con motivo de su centenario en el Palazzo Grasi de Venecia (12 de septiembre de 2004- 16 de enero de 2005), Madrid, La esfera de los libros, 2004, pp. 208-219. (Edición a cargo de Dawn ADES); CIRLOT VALENZUELA, Lourdes, "Salvador Dalí y sus influencias" en AA. VV., Historiografia i crítica al segle XXI, Barcelona, Universitat de Barcelona, 2004, p. 11; HERRERO, Raúl, "Salvador Dalí a golpe de Lautréamont" en Revista Bacarola, Barcelona, nos. 68-69, noviembre 2006, pp. 216-218; BUTAZZONI, Fernando, "Luz de arriba, luz de abajo" en Revista Bacarola, op. cit., pp. 181-186; BRETON, André, Diccionario del surrealismo, Buenos Aires, Losada, 2007, p. 40; PARCERISAS, Pilar, "Dalí y Ducasse. La sombra de Maldoror" en VV. AA., Catálogo de la exposición Salvador Dalí. Les Chants de Maldoror. 1934, (Del 13 de marzo de 2010 al 31 de diciembre de 2010), Figueres, Distribucións d'Art Surrealista, 2010, pp 133-139. (Comisaria Juliette MURPHY). Si bien éste parece ser el texto definitivo, lo cierto es que, en gran parte de la obra de Pilar PARCERISAS, es común el acercamiento a Lautréamont desde el surrealismo. A continuación enumeramos las páginas salpicadas por la sombra del conde: "Introducción" en VV. AA., Catálogo de la exposición Dali: afinidades electivas (Del 19 de febrero al 18 de abril de 2004), Barcelona, Fundación Gala-Salvador Dalí, Generalitat de Catalalunya, 2004, pp. 28-29. (Edición a cargo de Pilar PARCERISAS); "Salvador Dalí y Marcel Duchamp: una partida de ajedrez (con Raymond Roussel, Georges Huguet, André Breton y Man Ray, como voyeaurs" en VV. AA., Catálogo de la exposición Dalí: afinidades electivas, op. cit., p. 113; "Lautréamont y el magnetismo de los tiempos modernos" en Revista Bacarola, op. cit., pp. 151-154; Duchamp en España, Madrid, Siruela, 2009, pp. 27-37; MURPHY, Juliette, "Les Chants de Maldoror: documentación y proceso creativo", en VV. AA., Catálogo de la exposición Salvador Dalí. Les Chants de Maldoror. 1934, op. cit., pp. 139-144. DÍAZ GONZÁLEZ, Elisa María, "Aguafuerte y Heliograbado: consideraciones entorno a Les Chants de Maldoror" en VV. AA., Catálogo de la exposición, Salvador Dalí. Les Chants de Maldoror. 1934, op. cit., pp. 145-150; MOURE PAZOS, Iván, El bestiario del Conde de Lautréamont: la invocación daliniana, Santiago, USC; del mismo autor las siguientes obras: "Víctimas y verdugos en las ilustraciones de Les Chants de Maldoror de Dalí" en Anuario del departamento de historia y teoría del arte de la universidad autónoma de Madrid, $\mathrm{n}^{\circ}$. 22, 2010, pp. 225-239; "Sobre el Conde de Lautréamont y el arte surrealista", en Asociación Aragonesa de Críticos de Arte, $\mathrm{n}^{\circ}$. 14, marzo de 2011, s/p (edición electrónica); "Las ilustraciones de Les Chants de Maldoror de Dalí: la carnalidad de los objetos", en Quintana, no. 10, 2011, pp. 227-237; "Últimas hipótesis sobre el Conde de Lautréamont y Dalí: escritos y obra plástica", en Arte, Individuo y Sociedad, Vol. 24, $\mathrm{n}^{\circ} .1,2012$, pp. 39-57; "Nuevas hipótesis sobre La miel es más dulce que la sangre de Dalí", en Archivo Español de Arte, $\mathrm{n}^{\circ} .338,2012$, pp. 181-192.

5 Un claro ejemplo de esta correspondencia pudieran ser las ilustraciones de L'Encyclopédie 1751-1772 de DIDEROT y D'ALEMBERT. 
montiana (máquinas de coser, paraguas, cisnes...). La asociación texto-imagen, creaba estereotipos de significación solamente revelados tras un profundo conocimiento de la obra ducassiana y del patrimonio afectivo del propio artista; lo que en cierta medida, vino a obstaculizar la clara comprensión de esta dialogicidad.

\section{El cruce de disciplinas}

Lo anteriormente citado nos pone sobre la senda de una problemática secular ${ }^{6}$ : la polémica entre texto e imagen ${ }^{7}$. A grosso modo, las posturas triunfantes a la hora de resolver esta interacción entre las artes son dos: una unificadora y otra diversificadora. La primera no hace distinción entre texto e imagen, al considerarse ambas opciones como parte de una misma cultura ${ }^{8}$; lo que entendemos popularmente como la horaciana Ut pictura poesis ${ }^{9}$. La segunda establece sus propios parámetros de estudio e intenta explicar esta interrelación sirviéndose de procedimientos propios de cada disciplina ${ }^{10}$. Sobre este particular argumenta Antonio Monegal:

"Vivimos cada vez en un entorno cultural que contradice a Lessing: donde las artes ya no pueden dividirse en temporales y espaciales, porque tanto el cine como otros medios audiovisuales han acabado con tal distinción, y donde los artistas persiguen justamente la rotura de las barreras entre las artes y se entregan a las formas híbridas e impuras, experimentando con todas las posibles variedades de la contaminación" ${ }^{11}$.

La relación entre Lautréamont y el surrealismo se ha desarrollado en un mismo plano simbólico, y se inscribe en esa primera opción que escinde tanto contenido como forma, a favor de una mejor transferencia del símbolo iconográfico ${ }^{12}$. No sin razón, aclara Wendy Steiner:

6 MARKIEWICZ, Henryk, "Ut pictura poesis: Historia del topos y del problema”, en VV. AA., Literatura $y$ pintura, Madrid, 2000, p. 76. (Introducción, compilación de textos y bibliografía, a cargo de Antonio MONEGAL).

7 Tema inabarcable, tratado, de manera magistral, por MONEGAL, Antonio, En los límites de la diferencia. Poesía e imagen en las vanguardias hispánicas, Madrid, Tecnos, 1998.

8 Respecto a este primer posicionamiento unificador que remite al wagnerismo, al simbolismo y en general a al cuestión de la Gesamtkunstwerk (obra de arte total), se recomiendan las siguientes lecturas: STEINER, Wendy, "La analogía entre la pintura y la literatura", en VV. AA., Literatura..., op. cit., pp. 25-49. Así como el excelente artículo de MARKIEWICZ, Henryk, op. cit., pp. 51-86.

9 MUÑOZ D'IMBERT, Silvia, "Les Chants de Maldoror: la construcción de la máquina de lectura" en VV. AA., Catálogo de la exposición Dali: afinidades electivas...op. cit., p. 361. A propósito de Lautréamont y el surrealismo argumenta: "De modo que es posible utilizar aquella máxima horaciana Ut Pictura Poesis, para destacar la riqueza de las relaciones entre pintura y poesía en el surrealismo, con el fin de crear un metalenguaje para la revelación radical de la imagen".

10 Dentro de esta concepción más restringida, se sugieren los siguientes artículos: LAUDE, Jean, "Sobre el análisis de poemas y cuadros", en VV. AA., Literatura ..., op. cit., pp. 89-109. Así como KIBÉDI VARGA, Aron, "Criterios para describir las relaciones entre palabra e imagen", en VV. AA., Literatura..., op. cit., pp. 109-139.

11 MONEGAL, Antonio, "Introducción” en VV. AA., Literatura ..., op. cit., p. 10.

12 Los vínculos entre texto e imagen en el surrealismo ya han sido subrayados por, CAWS, Mary Ann, The art of the interferente: stressed readings in verbal and visual texts, Princeton, Princeton University Press, 1988. En dicho libro, la autora denomina al tránsito entre lo verbal y lo visual como "Stressed readings". 
“[...] el rasgo común de todas las artes es que evocan imágenes (por el medio que sea), apelando por tanto a los sentidos, especialmente a la vista. En tanto que utiliza imágenes visuales, la literatura es una pintura hablante, $\mathrm{y}$, puesto que las imágenes pictóricas se ofrecen abiertamente para ser vistas, entonces la poesía sería claramente un arte imaginístico. Las imágenes crean dos tipos de vínculos entre las artes. El primero de ellos es objeto de la crítica ejercida por la escuela iconográfica en la crítica de arte $[\ldots]$ El arte iconográfico implica la transferencia de símbolos e historias de un arte a otro" $"$.

Dentro de este contexto visual se mueve Gilbert Durand, en ese pequeño librito titulado Lo imaginario (2000), en el que vincula, entre otros movimientos, al primer surrealismo con el "triunfo de la imagen", opuesto, en todo caso, a lo que el autor denomina como "iconoclasia endémica" 14 :

“[...] Romanticismo, Simbolismo y Surrealismo fueron los bastiones de la resistencia de los valores de lo imaginario en el seno del reino triunfante del cientifismo racionalista, en el corazón de estos movimientos es donde se establece progresivamente una revaluación positiva del sueño, del ensueño, incluso de la alucinación [...]"15.

Rompiendo los límites de lo racional, el surrealismo demandó una renovada concepción de la imagen; una exaltación de la imagen visionaria que fructificaría en unas serie de repertorios iconográficos alucinados, individuales y personalizados ${ }^{16}$. La conexión entre poesía e imagen, imagen y poesía, resultaba obvia. Dentro de este contexto, se inserta la retratística maldororiana que a continuación presentamos. El héroe de Les Chants de Maldodor, será representado en numerosas ocasiones, pero siempre de manera diferente. El caso de su retratística, nos sitúa ante uno de los mejores ejemplos de esta interacción entre lo leíble y lo visible de este fecundo diálogo.

\section{Los retratos de Maldoror}

Lautréamont opta por la aniquilación misma de su personaje. No tiene cara ni forma definida y se manifiesta a través de múltiples trasmutaciones poéticas ${ }^{17}$. Esta dinamogenia nos permite situar al heroico Maldoror como un ser fantástico, un monstruo. Las diferentes manifestaciones de esta entelequia, son aliciente primordial para aquellos artistas que quisieron poner límite, mediante trazo y dibujo, a la inconcrección de

13 STEINER, Wendy, op. cit., p. 37. Contrario a este argumento se encuentran las tesis de Jean LAUDE, op. cit., pp. 90-91. En ellas se propone una emancipación de las artes: "La pintura ya no hace referencia a una disciplina imaginaria que le es ajena, ni se apoya en los textos escritos", y sentencia, "Nuestra tarea consiste en plantear el análisis a un nivel diferente de aquel nivel en que la iconografía y la iconología lo han mantenido hasta ahora".

14 DURAND, Gilbert, Lo imaginario, Barcelona, Ediciones del Bronce, 2000, pp. 23-30.

15 IBIDEM, p. 53.

16 No debemos obviar que, dicho movimiento, fue especialmente prodigo a la hora de romper con las barreras entre imagen y texto. Fruto de este empeño fue la denominada poesía visual, que aunaba en un mismo contexto lo icónico con lo verbal.

17 SCHNEIDER, Marcel, Histoire de la littérature fantastique en France, Paris, Librairie Arthéme Fayard, 1985, p. 142. 
su figura. Los disfraces de Maldoror son múltiples y diversos (animales, vegetales, cosas), y suelen utilizarse como táctica de ataque contra sus adversarios: Dios, el hombre y los Seres Seráficos.

Entre Maldoror y su creador existen ciertas concomitancias que debemos reseñar. Ambos son entes fantasmáticos. Actualmente, la vida de Lautréamont sigue siendo un enigma. Se especula con su identificación, llegándose a afirmar que la foto que publica Jacques Lefrère en Le visage de Lautréamont (1977) es el mismísimo Lautréamont; algo totalmente mercantilizado y ampliamente socializado, pero a todas luces, incierto [fig. 1] ${ }^{18}$. Por lo tanto, cabe ser cautos y argumentar, en palabras de Manuel Serrat, que: "Lo primero que llama la atención en la biografía de Isidore Ducasse es que, un hombre que vivió en la segunda mitad del siglo XIX consiguiera dejar tan pocos testimonios documentales de su existencia" 19 . Partiendo de la premisa de la incertidumbre, no será extraño que Dalí en 1937 -tres años después de ilustrar Les Chants de Maldoror- ponga rostro a un joven Lautréamont a través de su método paranoico-crítico [fig. 2] ${ }^{20}$. El resultado es un busto imaginario que "se debate entre la luz y la sombra, donde el pintor, polariza el claro-oscuro, no como artificio plástico, sino simbólico, aludiendo a lo desconocido, que es lo mistérico en Lautréamont" 21 . Con ello, Dalí materializa su más oscura obsesión, quizás la más salvaje de sus primeros tiempos ${ }^{22}$. Otros intentos por recrearse en este maravilloso ejercicio interpretativo, han sido las estupendas obras de Félix Valloton, Comte de Lautréamont (1896), la sorprendente tinta de Juan Batlle Planas, Verdadero retrato del Conde de Lautréamont hecho por Juan Battle Planas quien fue su contemporáneo y amigo (1942), o la acuática retratística de Wifredo Lam y su policéfalo Lautréamont $(\mathrm{s} / \mathrm{f})^{23}$.

18 Vid. LEFRÈrE, Jacques, Le visage de Lautréamont, Paris, Pierre Horay éditeur, 1977.

19 SERRAT CRESPO, Manuel, "Introducción” en Lautréamont, Conde de, Los cantos de Maldoror, Madrid, Cátedra, 2008, p. 34.

20 PARCERISAS, Pilar, "Introducción”, op. cit., p. 28. La autora víncula el método paranoico-crítico de Dalí con la obra de Raymond Roussel, en especial con sus obras, Impressions d'Afrique (1910) y Locus Solus (1914): "El método paranoico que Roussel desarrolla con el lenguaje, es sin lugar a dudas, un modelo precursor del método paranoico-crítico de Dalí". Sobre "escritura paranoica", se recomienda la consulta de, LEYRA, Ana María, De Cervantes a Dalí. Escritura, imagen y paranoia, Madrid, Fundamentos, 2006. También, relativo al método paranoico-crítico ver la entrada de, VISA, Miquel, Dalicedario, Lleida, Milenio, 2003, pp. 131-137.

21 MOURE PAZOS, Iván, "Últimas hipótesis...", op. cit., p. 41.

22 PARCERISAS, Pilar, "Dalí y Ducasse...", op. cit., p. 134. Vincula al retrato de Lautréamont con el Autorretrato (1921) de Dalí. Una hipótesis que juzgamos teóricamente válida (máxime si consideremos el juego mimético de Dalí para con Ducasse). Quisiera reproducir el fragmento de la autora, por considerarlo sumamente original y atrevido: "El resultado fue un dibujo de candidez espectral, que muestra la doble imagen (luz y sombra) de un ser joven, de aspecto andrógino y a un tiempo monstruoso. ¿Es Maldoror? ¿Es Mervyn, el adolescente seducido, perseguido y asesinado por Maldoror en el Canto VI? ¿O son ambos a la vez? La mirada es cruel, ciclópea, de un único ojo. Dalí dibujó a Lautréamont emulando el autorretrato que el mismo se había hecho unos años atrás cuando tenía unos diecinueve".

23 MOURE PAZOS, Iván, El bestiario..., op. cit., p. 211. 


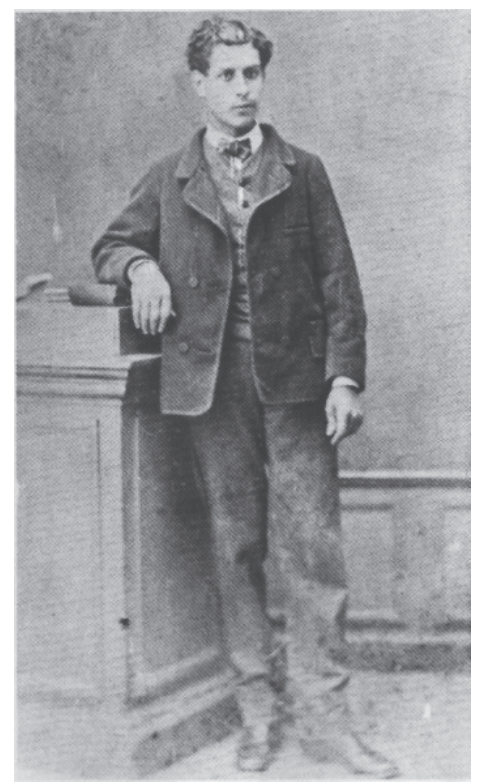

Fig. 1: Retrato fotográfico supuestamente de Isidore Ducasse, identificado por Jacques Lefrère. Col. Particular. (SERRAT CRESPO, Manuel, "Introducción", en Lautréamont, Conde de, Los Cantos de Maldoror, Madrid, Cátedra, 2008, p. 8).

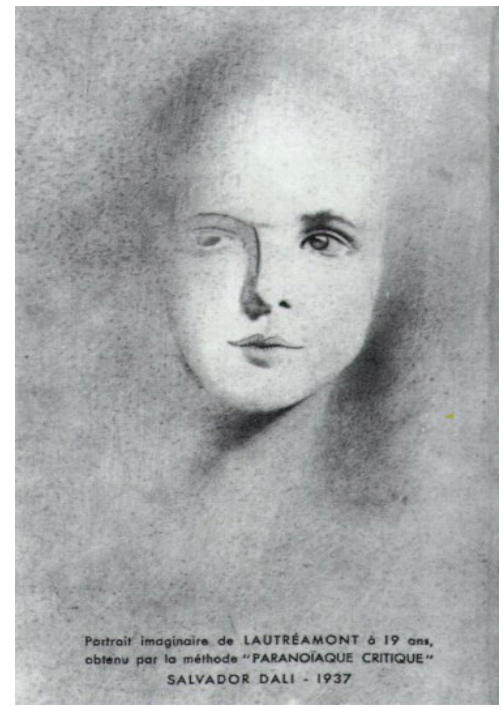

Fig. 2: Dalí. Portrait imaginaire de Lautréamont á 19 ans, obtenu par la méthode paranoiaque critique. 1937. Col. Librairie Jose Corti. (PARCERISAS, Pilar, "Dalí y Ducasse. La sombra de Maldodor" en VV. AA., Catálogo de la exposición Salvador Dalí. Les Chants de Maldoror. 1934, del 13 de marzo de 2010 al 31 de diciembre de 2010, Figueres, Distribucións d'Art Surrealista, 2010, p. 9. Comisaria Juliette MURPHY). 


\subsection{Dalí: Maldoror como jinete lúgubre}

Al igual que Lautréamont, Maldoror será representado en diferentes estados y formas. El primer registro de esta emulsión pictórica la encontramos en Dalí y sus delirantes ilustraciones para Les Chants de Maldoror (1934) ${ }^{24}$. En ellas, se lleva a cabo una interpretación libre de la obra ducassiana, donde covergen varias de las obsesiones del artista $^{25}$ : El Angelus (1859) de Millet, la pasión delirante por Napoleón, el discurso sobre antropofagia y caníbalismo, los traumas afectivos, y un sin fin de elementos barroquizantes que tendrán como fin último, la reinterpretación desprejuiciada del pasaje lautreamontiano ${ }^{26}$. Maldoror se manifiesta aquí como jinete lúgubre [fig. 3]. Dalí toma el célebre pasaje del Canto III de Les Chants de Maldoror para mostrarnos a un Maldoror cruel y abominable. La acción transcurre en un paisaje destronado de belleza:

"Lautréamont entremezcla dos historia paralelas, una real con otra legendaria. En la primera nos muestra a un Maldoror enamorado que se dispone a galopar por la playa con su amigo Mario, "beau comme la fleur du cactus". La segunda, se introduce a través de la mirada de un campesino que los confunde con "les deux fréres mystérieux" 27. Es entonces cuando el idilio muta en tenebrismo y nos narra la historia de los dos hermanos misteriosos: estos jinetes, a galope de caballos con alas negras, reaparecen en épocas de desgracia para orbitar junto al sol o desplazarse al fondo de los cráteres, con el fin de asolar la tierra de maldad y destrucción, en clara alusión a los jinetes bíblicos del apocalipsis" 28 .

En la lámina de Dalí, nos sorprende un Maldoror a la vez jinete y zombie. Un Maldoror, que enlazaría por afinidad ósea, con el fantasmagórico retrato de Kurt Seligmann que se ofrece a continuación. El jinete lúgubre no tiene piedad, su caballo, igualmente no muerto, se muestra impasible al empalamiento de sus víctimas; un conglomerado de carnes sectorializadas suspendidas verticalmente por agujas de coser. Con ello, Dalí pretende un retrato fiel de dicho jinete en su faceta más aniquiladora e intención apocalíptica ${ }^{29}$.

24 Vid. LAUTRÉAMONT, Comte de, Les Chants de Maldoror, Paris, Albert Skira, 1934, (dessins de Salvador Dalí).

25 MOURE PAZOS, Iván, "Víctimas y verdugos...", op. cit., pp. 225-239.

26 DESCHARNES, Robert, NÉRET, Gilles, op. cit., p. 211. En dichas páginas se nos aclara "Mientras trabajaba en el taller Lacourière en los grabados para Los cantos de Maldoror se reencontró con Picasso, quien lo había presentado a Skira y sugerido a este último la idea de hacer ilustrar un libro por Dalí. En sus pausas durante el trabajo, los dos realizan un grabado común, alternándose en el tratamiento de la placa. Se trata de la obra Figures Surrealistes". Esta primera afirmación, es desmentida por, GIBSON, Ian, La vida desaforada ..., op. cit., p. 399. "En 1948 Skira afirmaría con rotundidad que fue René Crevel quien le convenció de que debería contratar a Dalí para la edición de Los Cantos de Maldoror. Ello tiende a desmentir la versión posterior de Dalí según la cual el encargo fue el resultado de una intervención por parte de Picasso".

27 LAUTRÉAMONT, Conde de, "Los cantos de Maldoror" en Obra completa bilingüe, Madrid, Akal, 1988, p. 248. (Trad. ALVAREZ ORTEGA, Manuel).

28 MOURE PAZOS, Iván, "Les Chants de Maldoror y la Biblia a través de la iconografía bestiaria”, en Castilla, Estudios de literatura, no. 2, 2011, p. 284.

29 MOURE PAZOS, Iván, El bestiario...op. cit, p. 148. 
Posteriormente, volverá a reincidir en esta retratística a través de su extraordinario óleo Le Cavalier de la mort (1935), que es una conclusión de su predecesora para Les Chants y excelente continuadora de este fasto lúgubre ${ }^{30}$. De nuevo Maldoror reaparece, al igual que su caballo, muerto y vivo, sólo que esta vez, más templado, luce sin víctimas paseante por el arenal de Cadaqués; una escena que bien pudiera sugerirnos una mímesis, la preferida por Dalí con Maldoror, o en clave paisajera, la de la playa maldororiana con la costa catalana ${ }^{31}$. Un paisaje velado, interpelado de febril romanticismo: ruinas, mar y cielo, radiografiados por un arco iris. Una suerte para la recreación bucólica, potenciada por la misantropía de aquel que rehúye al hombre. El Maldoror de Dalí no conoce medida, reposa o mata.

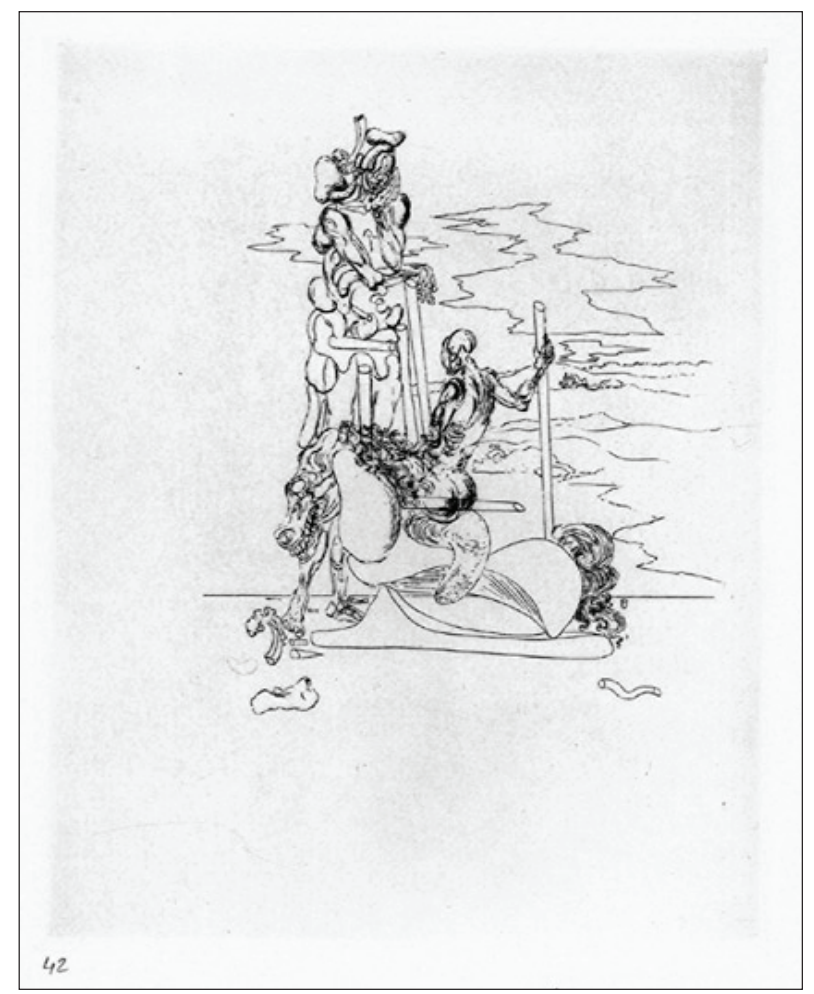

Fig. 3: Dalí. Ilustración para Les Chants de Maldoror: Le Cavalier et la mort. 1934. Col. Particular. (VV. AA., Catálogo de la exposición Salvador Dalí. Les Chants de Maldoror. 1934, del 13 de marzo de 2010 al 31 de diciembre de 2010, Figueres, Distribucións d'Art Surrealista, 2010, p.111. Comisaria Juliette MURPHY).

30 IDEM.

31 S. LUBAR, Robert, "Diccionario”, en VV. AA., Catálogo de la exposición Dalí, op. cit., p. 441. Pone en relación el paisaje de las ilustraciones de Les Chants con el Empordà natal del pintor. "[...] Dalí situó su imaginería masoquista en un entorno concreto: las fértiles llanuras de su Empordà natal, subrayando así el trauma narcisista de autoaniquilación como un proceso de destrucción y regeneración casi geológico y cíclico bajo impulso eterno de la compulsión de la muerte". 


\subsection{Kurt Seligmann: Maldoror hibridado}

En 1938, André Breton reúne a lo mejor del surrealismo francés para ilustrar -al igual que lo había hecho Dalí- Les Chants de Maldoror ${ }^{32}$. Kurt Seligmann, André Masson, Max Ernst, Victor Brauner, Man Ray, Yves Tanguy, Óscar Domínguez, Agustín Espinoza, René Magritte, Joan Miró, Roberto Matta, Wolfgang Paalen, serán algunos de los artistas elegidos para trabajar en esta edición, en la que no pocos se vieron tentados a plasmar la esencia de Maldoror.

Una de las láminas más sorprendentes es, sin duda, la de Kurt Seligmann [fig. 4]. El autor nos ofrece un retrato de Maldoror gigantizado, que es una hibridación de las múltiples metamorfósis que sufre. Como es común, Kurt Seligmann crea su propio Maldoror con fractales de diferentes pasajes lautreamontianos; un collage iconográfico. El resultado es una masa informe, con alas de cisne, carnes detumescentes, espermatozoides alados y murciélagos, enmarcados por un paisaje pleistocénico ${ }^{33}$. Más allá de su mero valor intrínseco, la obra es importante porque crea discurso iconográfico; es decir, asienta una tipología figurativa de Maldoror. Una tipología que veremos de nuevo a través de las estupendas imágenes hibridadas de Une écriture lisible (1938), y Phantom of the past (1942) [figs. 5-6].

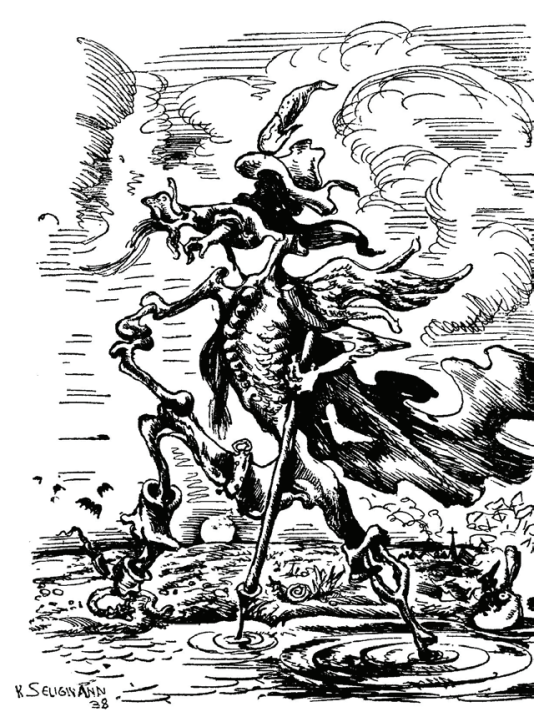

Fig. 4: Kurt Seligmann. Ilustración para Les Chants de Maldoror: Retrato de Maldoror. 1938. Col. BnF. (LAUTRÉAMONT Conde de, Obra completa, Buenos Aires, Argonauta, 2007, p. 304. Introducción de Aldo PELLEGRINI).

32 LAUTRÉAMONT, Comte de, "Les Chants de Maldoror" en Oeuvres Complètes, Paris, G.M.L., 1938. (préface de André Breton, dessins de Victor Brauner, Óscar Domínguez, Max Ernst, Agustín Espinoza, René Magritte, André Masson, Joan Miró, Roberto Matta, Wolfgang Paalen, Man Ray, Kurt Seligmann, Yves Tanguy).

33 Con ánimo de no demorarnos más en las innúmeras contaminaciones iconográficas de esta lámina, remitimos a: MOURE PAZOS, Iván, El bestiario..., op, cit., pp. 59-111. 


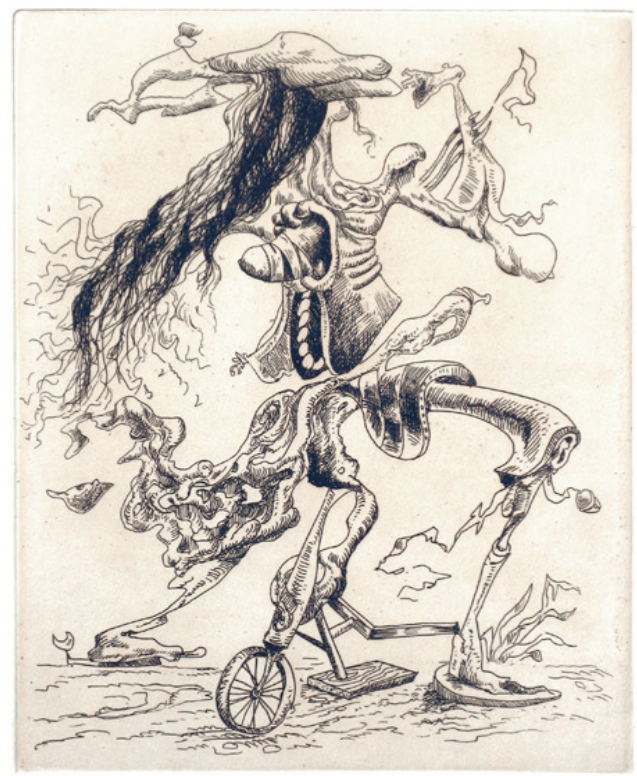

Fig. 5: Kurt Seligmann. Une écriture lisible. 1938. Col. Particular. [www.mchampetier. com/Etching-Kurt-Seligmann-19389-work-html]. (Consultado el 3 del 3 de 2011).

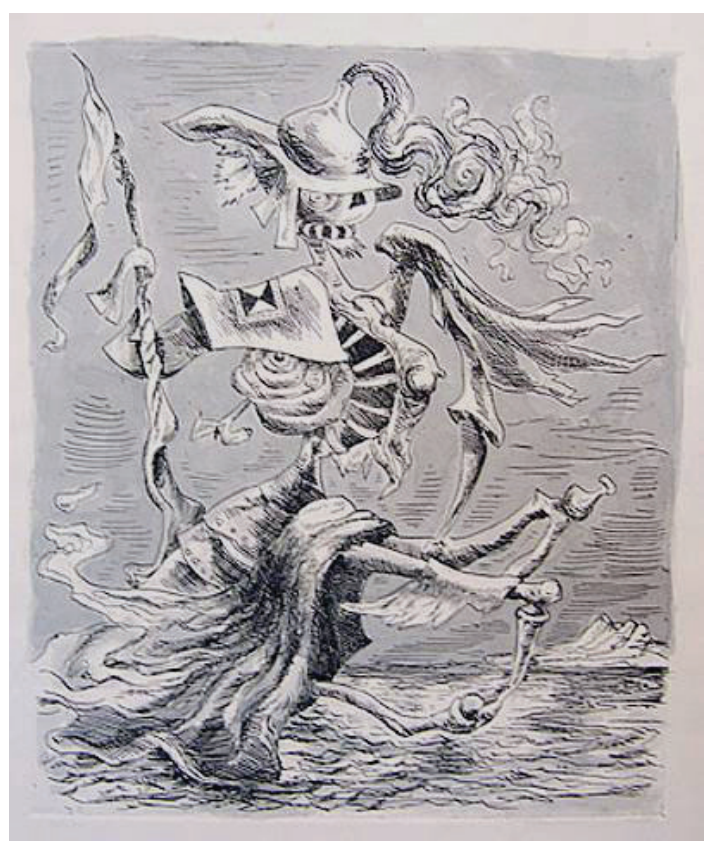

Fig. 6: Kurt Seligmann. Phantom of the Past. 1942. Col. The Cleveland Museum of Art. [www. Clevelandart.org]. (Consultado el 3 del 3 de 2011). 


\title{
2.3 Andre Masson: Maldoror parasitado
}

Menos abstracta, será la obra de Andre Masson para la misma edición [fig. 7]. El artista opta por la representación del Maldoror parasitado, que es, además, uno de los pasajes más celebrados de la obra ducassiana ${ }^{34}$. Se trata del emblemático Maldoror tomado por las alimañas del Canto $I V$. En resumidas cuentas, el héroe Lautreamontiano alberga sapos y camaleones en sus axilas que devoran la grasa de sus costillas; una víbora engulle su verga; el interior de sus testículos son dos erizos; su ano ha sido ocluido por un cangrejo, y dos medusas se han instalado en sus glúteos. Para Ana Alonso:

\begin{abstract}
"Todos estos animales pertenecen a especies inferiores, insectos, batracios y reptiles, muchos de ellos con capacidad de mutar y relacionados con el agua; poseen además formas que se adecuan al órgano o zona corporal parasitada. Se instalan en la anatomía del personaje sin crear nuevos volúmenes, lo que permite subrayar que, tras el aparente ensamblaje disparatado, hay un intento de estructuración por parte del autor, visible también en la elección de las zonas ocupadas: zonas erógenas en las que Maldoror recibe agresiones no exentas de un componente de placer. Se trata además de espacios cóncavos que, rellenados por formas animales, despojan de entidad la anatomía humana" ${ }^{35}$.
\end{abstract}

Pero lejos de poner fin a su flagelación, Lautréamont exorna su canto a la mugre con vegetaciones, tornándose en imagen archimboldesca. Es aquí donde reside la verdadera extrañeza de esta transgresión. Ya Bachelard había advertido sobre la escasa incidencia de las formas vegetales en Les Chants $^{36}$. Ahora Ducasse, introduce la vegetación como elemento de agresión: en la nuca de Maldoror crece una enorme seta de umbelíferos pedúnculos, sus pies han echado raíces y hasta su vientre se extiende una frondosa vegetación portadora de innobles parásitos. Como colofón final, la columna de Maldoror es una espada hendida que lo inmoviliza.

Andre Masson, materializa esta pesadilla tornándose el mejor cronista de la desgracia maldororiana, eso sí, introduciendo alguna contaminación iconográfica, como el detalle del pulpo alado, que no pertenece al Canto IV sino al II. El barroquismo visual inunda toda la obra, ofreciéndonos el único retrato existente sobre el Maldoror parasitado, que es probablemente la piedra angular de gran parte de su producción futura. Véase como ejemplo la teratológica Il n'y a pas de monde achevé en Mythologie de la nature (1938) [fig. 8].

34 LAUTRÉAMONT, Conde de, "Los cantos...”, op.cit., p. 334.

35 ALONSO GARCÍA, Ana Isabel, "Metamorfosis ducassianas: un universo inestable" en Revista Bacarola...op. cit., p. 160.

36 BACHELARD, Gaston, Lautréamont, Paris, Librairie José Corti, 1939, p. 12. 


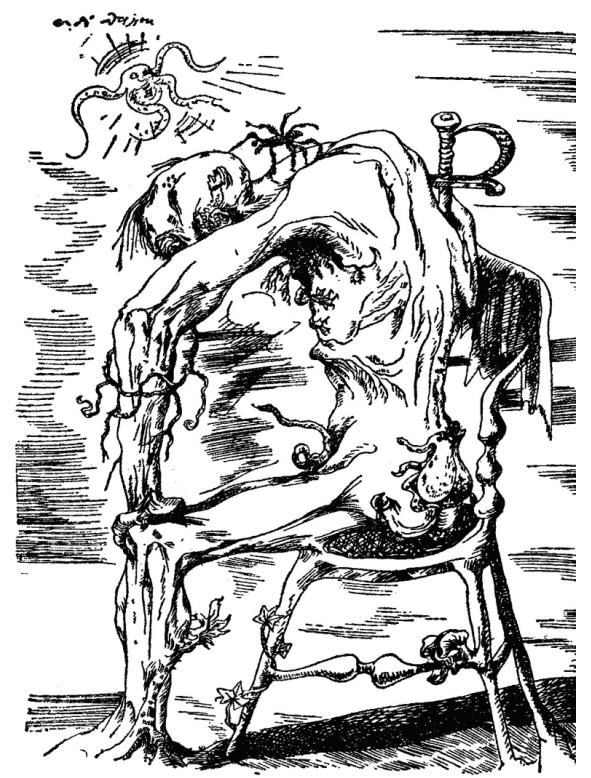

Fig. 7: André Masson. Ilustración para Les Chants de Maldoror: Maldoror parásitado. 1938. Col. BnF. (LAUTRÉAMONT Conde de, Obra completa, Buenos Aires, Argonauta, 2007, p. 202. Introducción de Aldo PELLEGRINI).

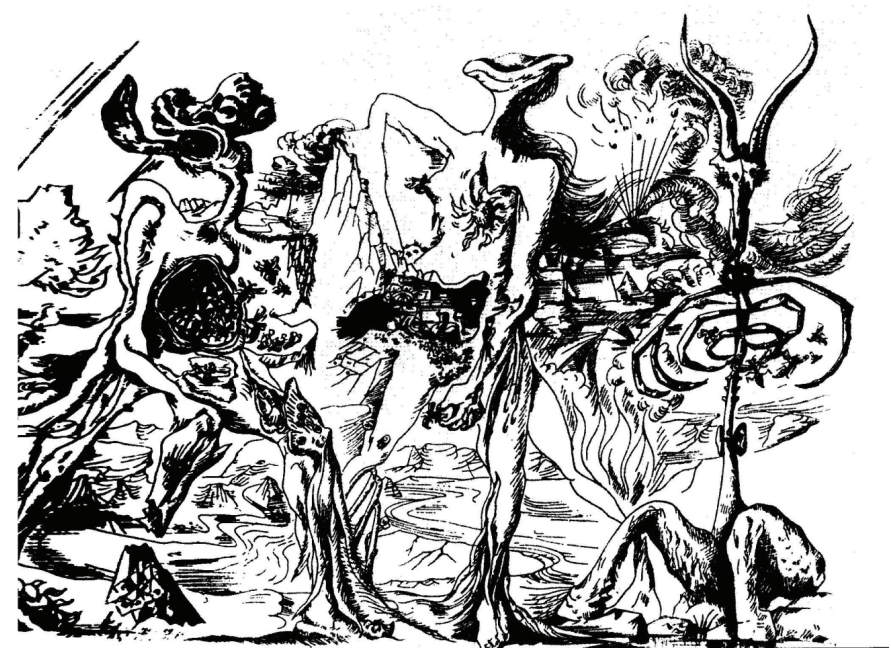

Fig. 8: André Masson. Il n'y a pas de monde achevé en Mythologie de la nature. 1938. Referente al Maldoror parasitado. Col. Particular. (VV. AA., Catálogo de la exposisción André Masson. 1896-1987, del 29 de enero de 2004 al 19 de abril de 2004, Madrid, Museo Nacional de Arte Reina Sofía, 2004, p. 214. Comisaria Josefina ALIX). 


\subsection{Max Ernst: Maldoror cosificado}

Llegamos así al retrato que Max Ernst realiza para Maldoror. El artista se inspira -al igual que Andre Masson- en un pasaje del Canto IV: el del Maldoror cosificado. Concretamente, Ernst toma el comienzo de dicho Canto, donde Maldoror, a través de un monólogo interior, no se sabe persona, árbol, o piedra [fig. 9]. Lautréamont permeabiliza la frontera entre lo vivo y lo inerte en pos de una poesía que -como dirá Ricard Ripoll- todo lo puede, "porque las palabras lo dicen" ${ }^{37}$. Ese desborde delirante subvierte las fronteras de lo establecido y condena a Maldoror a uno de los castigos más cruentos del recetario lautreamontiano, la quietud o la imposibilidad de movimiento como indefensión ante un mundo despiadado. Un universo donde se hiperboliza la maldad a través de comportamientos abominables como el canibalismo, la necrofilia, y el cainismo ${ }^{38}$. El fin de este empeño, como bien podremos intuir, será la creación de una realidad delusiva, conturbadora de nuestros miedos más profundos. El ser humano, tendente al control, deberá resignarse al capricho de un mundo volátil y arbitrario, un mundo que rige la conducta del hombre y no viceversa. Ahora Ernst, introduce la tipología del Maldoror cosificado; una tipología que encontará una enorme fortuna en futuras representaciones surrealistas, como el Hombre-pelicano transmutado en faro de Magritte para Maldoror (1948) [fig.10] ${ }^{39}$, o el afamado Pterodáctilo (1959) de Remedios Varo.

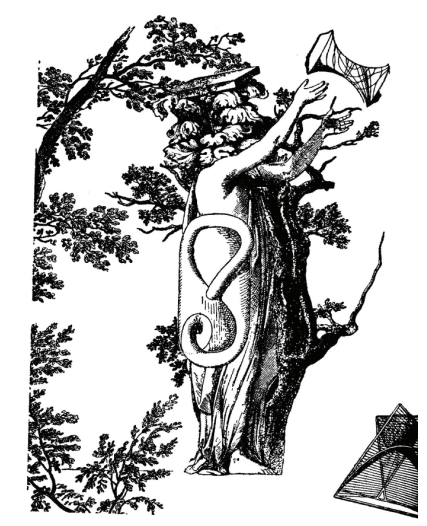

Fig. 9: Max Ernst. Ilustración para Les Chants de Maldoror: Maldoror metamorfoseado en árbol y piedra. 1938. Col. BnF. (LAUTRÉAMONT Conde de, Obra completa, Buenos Aires, Argonauta, 2007, p. 174. Introducción de Aldo PELLEGRINI).

37 RIPOLL, Ricard, "La verdad práctica de Isidore Ducasse, conde de Lautréamont” en Revista Bacarola... op. cit., p. 150.

38 El cainismo es un tipo de conducta agresiva observada en algunos animales, principalmente aves rapaces, que consiste en la destrucción del hermano (o hermanos menores) por parte del más fuerte, que a partir de entonces pasa a acaparar la comida y atención de sus padres. En algunas especies, como el águila real, los progenitores no se inmutan cuando presencian esta actividad, mientras que en otros animales las conductas cainitas se producen cuando los padres se han ausentado del nido. El nombre hace referencia a Caín, personaje bíblico que mató a su hermano Abel por celos. Otro ejemplo de cainismo sería el canibalismo intrauterino practicado por algunos tiburones ovovivíparos, en los que las crías más fuertes devoran los huevos de los padres aun sin eclosionar y a sus hermanos más débiles antes de abandonar el cuerpo de su madre.

39 Vid. LAUTRÉAMONT, Comte de, Les Chants de Maldoror, Brussels, Editions de la Boétie, 1948, (dessins de René Magritte). 


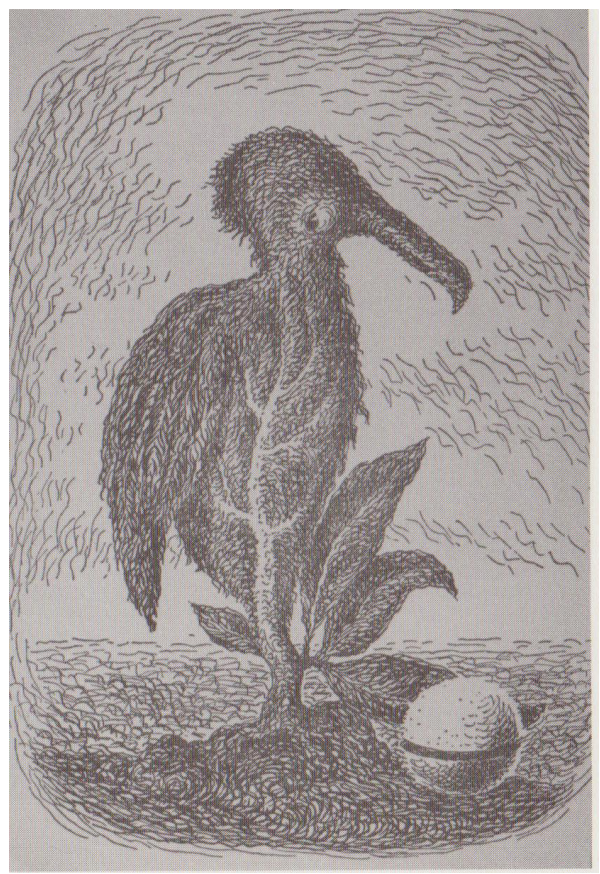

Fig. 10: René Magritte. Ilustración para Les Chants de Maldoror : Hombre-pelícano convertido en faro. 1948. Col. Particular. (HUBERT, Reneé Riese, Surrealism and the book, Berkeley: University of California Press, 1988, p. 204).

\subsection{Tanguy, Brauner, Magritte: del Maldoror personificado al Maldoror vampi- rizado}

Quisiera finalizar esta andadura por la retratística de Maldoror, con cuatro láminas inspiradas en el Canto $V$ de Les Chants de Maldoror. Se trata de las aportaciones de Yves Tanguy, Victor Brauner y René Magritte que, como un fundido encadenado, crearán un discurso narrativo secuenciado del pasaje lautreamontiano sintetizado en el siguiente fragmento:

"De todos los cantos, quizás el más complejo sea el Canto $V$. En él, Ducasse nos sumerge en un universo alucinatorio, en un juego de espejos divergentes que trastocan nuestra noción de realidad. Este caos narrativo se acentuará aún más con la incesante -casi irrespirable- sucesión de metamorfosis que actúan como elementos coadyuvantes de ambigüedad y potencia lírica. La fenomenología animalizante de Maldoror se torna arcóntica. Por allí transita el -anteriormente citado- hombre-pelícano de complexión humana y cabeza palmípeda, que acabará convirtiéndose en faro para advertir a los navegantes sobre las malas artes de las hechiceras. Entre tanto, éste dialoga con su hermano, un escarabajo gigante que transporta una bola de excrementos que resulta ser una mutilada mujer-hechicera atada con collares de perlas. La mujer a su vez es la culpable del transformismo de los dos hermanos. Mientras tanto, en el cielo se libra 
un encarnizado combate entre un Buitre y un Búho de Virginia, ambos despechados por el falso amor de la susodicha hechicera, ante la mirada atónita de Maldoror ${ }^{40}$. Lautréamont hace converger todas las escenas al mismo tiempo, a fin de crear una atmósfera inquietante y claustrofóbica. Es así como abandona o retoma el hilo narrativo a capricho dejando al lector desprovisto de todo anclaje argumentativo al que asirse. Ese "vertige" que dirá Blanchot ${ }^{41}$ se amalgama de "máquinas textuales"42 para orbitar sobre la inconcrección que nos expulsa hacia una lectura interior. Extenuados de barroquismo visual, nuestro desasosiego como espectadores se antepone al placer de Maldoror que como un voyeur presencia extasiado la innata maldad humana"43

Un Maldoror que, por primera vez, se materializa personificado, gracias al genio de Yves Tanguy, y su tinta para Les Chants de Maldoror [fig. 11] ${ }^{44}$.

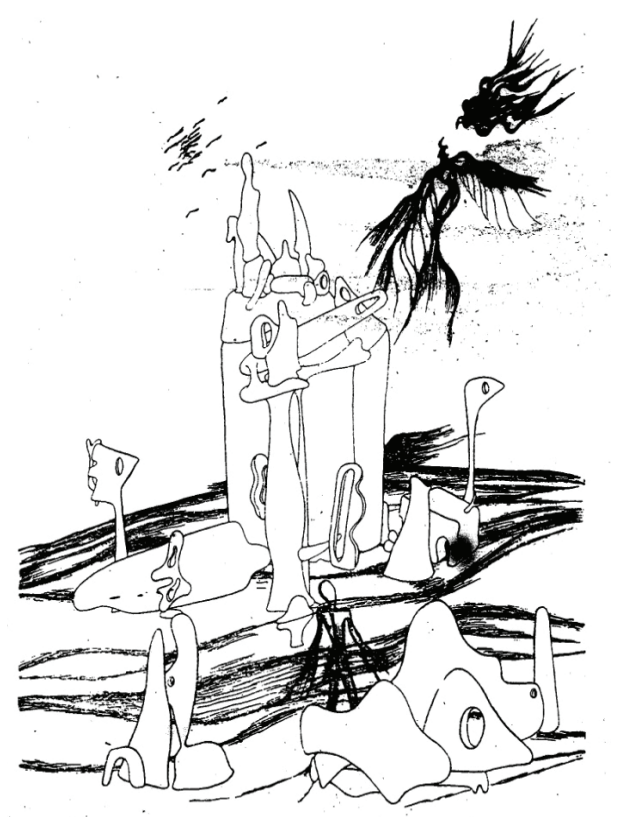

Fig. 11: Yves Tanguy. Ilustración para Les Chants de Maldoror: Maldoror en primer término, contemplando el combate entre el Buitre Leonado y un Búho de Virginia. 1938. Col.

BnF. (LAUTRÉAMONT, Comte de, "Les Chants de Maldoror" en Oeuvres Complètes, préface de André Bretón, dessins de Victor Brauner, Óscar Domínguez, Max Ernst, Agustín Espinoza, René Magritte, André Masson, Joan Miró, Roberto Matta, Wolfgang Paalen, Man Ray, Kurt Seligmann, Yves Tanguy, Paris, G.M.L.1938, p. 213).

40 LAUTRÉAMONT, Conde de, "Los cantos...”, op. cit., pp. 386-395.

41 BLANCHOT, Maurice, Lautréamont et Sade, Paris, Les Éditions de Minuit, 1978, p. 59.

42 RIPOLL, Ricard, "La verdad práctica de Isidore Ducasse, conde de Lautréamont" en Revista Barcarola, op. cit., p. 147.

43 MOURE PAZOS, Iván, “Les Chants...”, op. cit., p. 289.

44 MOURE PAZOS, Iván, El bestiario...op. cit, p. 81. 
Pero continuemos con el pasaje del Canto $V$. Ducasse no nos da tregua, cuando creemos otear ya a lo lejos el fin de ésta chirriante pesadilla, nos mece en cadencias vampíricas, el pulso se ralentiza y una araña irrumpe para succionar con su vientre el gaznate de Maldoror ${ }^{45}$. Más adelante, se nos revela que el arácnido es una metamorfosis humana: dos hombres son convertidos en una misma araña por un arcángel con el objeto de castigar a Maldoror. Cuando la araña abre su vientre, brotan dos adolescentes vestidos de azul con sendas espadas llameantes custodiando el lecho de la víctima. Maldoror se convierte en presa gozosa de dos gemelos intrauterinos, sedimentos del isomorfismo arácnido. Estos "fantômes de la succion" 46 nos envuelven en extraños pasajes de vampirismo, utilizados como mecanismo de introducción a ese mal onírico que es la pesadilla pausada. Antítesis de la fuerza agresiva, la precisión animal se antepone al desgarramiento como instrumentalización de ataque para sumergirnos en el terrorífico mundo de la ensoñación vampírica. El triunfo del sueño produce indefensión y quietud, circunstancia que ahorma la fluidez líquida: saliva, sangre y esperma. Nadie como Lautréamont, ha puesto en énfasis el placer recíproco de tal acción. Maldoror aporta una nueva concepción del vampirismo basada en la agresión consensuada como fuente de placer. Éste, en duermevela, consiente su desangre; es decir, erotiza la sangre en su entrega al arácnido. Enfermo de hedonismo, sucumbe al desenfreno de un ejercicio flebotómico: sangrarse en una "coupe d'orgie". Más que acertada nos parece la alusión de Santiago Mateos sobre este particular: "Sexualidad y vampirismo se vuelven a unir en un arrebato sadomasoquista en el que caricias y desgarros se entremezclan, en donde se confunden la condición de vampiro y vampirizado" ${ }^{47}$. Más aún, podremos concluir que a través de un mecanismo que anticipa el placer a la desgracia, la víctima parece tornarse victimario y viceversa.

Llegado de los Cárpatos -morada de Hombres-lobo y Nosferatus- e instigado por su padre al texto cabalístico, Victor Brauner, enseguida empatiza con el pasaje vampírico del Canto $V$, resolviéndolo a través de una personificación arácnida [fig. 12] ${ }^{48}$. Lo que hace el artista rumano es alterar el orden del pasaje subvirtiendo el tiempo narrativo; es decir, la araña brota del cuerpo humano y no viceversa. De todos modos, la obra está salpicada de múltiples alusiones al patrimonio afectivo del pintor que poco tienen que ver con el pasaje ducassiano, como los motivos oculares, inherentes prácticamente a toda la producción de Brauner.

45 LAUTRÉAMONT, Conde de, "Los cantos...", op. cit., pp. 430-448.

46 BACHELARD, Gaston, op. cit., p. 42.

47 MATEOS MEJORADA, Santiago, "De Gaspar de la Nuit a Les Chants de Maldoror: en torno al tema de la sangre" en Revista de Filología Francesa, Madrid, núm. 10, 1996, p. 160.

48 Toda la existencia de Victor Brauner, estuvo marcada por el ocultismo. A temprana edad, espiaba las sesiones de espiritismo de su padre, en las que el artista, contemplaba cosas extraordinarias: levitaciones, e incluso, nos dice, a gentes vulgares cantar como Caruso. Vid, [http://www.revista.agulha.nom.br/.] CARLOS. M. Luis: "Victor Brauner. El Mago", en Revista Aghulla. (Consultado el 13 de marzo de 2011). 


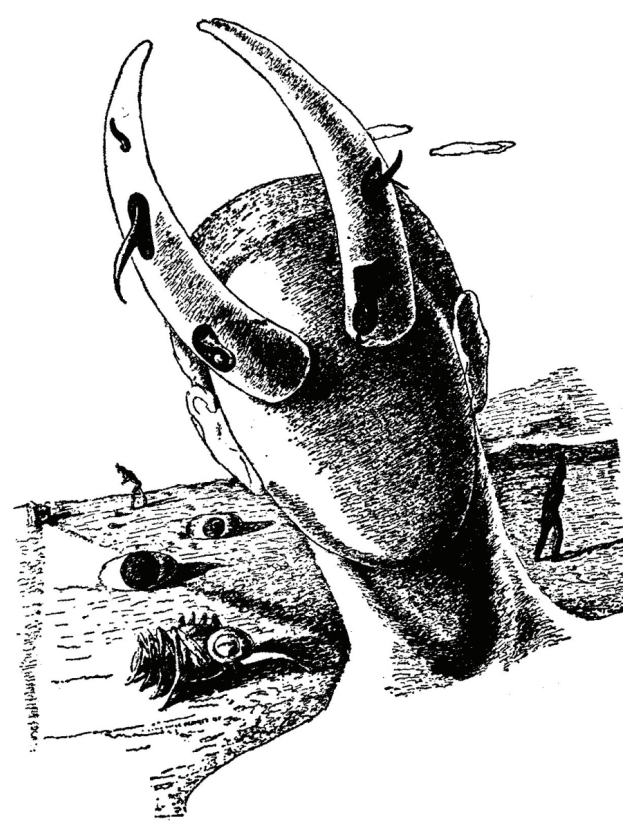

Fig. 12: Victor Brauner. Ilustración para Les Chants de Maldoror: Pasaje vampírico de la araña. 1938. Col. BnF. (LAUTRÉAMONT Conde de, Obra completa, Buenos Aires, Argonauta, 2007, p. 296. Introducción de Aldo PELLEGRINI).

Menos licenciosa será la representación de este mismo pasaje por René Magritte. A catorce años de la edición ilustrada de Les Chants por Dalí, Magritte hace lo propio deleitándonos con un recetario de imágenes lautreamontianas ${ }^{49}$. Al igual que Victor Brauner, el artista mostró especial debilidad por la representación del Maldoror vampirizado. No cabe duda de que el artista concibió la obra en su vertiente más sangrienta. Leamos la primera imagen, que es una advertencia a modo de portada: en la zona superior, un texto ensangrentado que enuncia el título de la obra, bajo él, la sombra de Maldoror succiona la cúpula del Palacio de Justicia de Bruselas. La lectura parece bastante clara: Maldoror ataca a partes iguales la justicia y la moralidad del hombre para instaurar la suya [fig. 13] ${ }^{50}$. Ignorando la advertencia de este prefacio, nos sumergimos en las amargas páginas del pintor belga. No podía ser de otro modo, Magritte sucumbe al pasaje arácnido mara mostrarnos a un Maldoror entregado a una vampirización gozosa. De nuevo -al igual que en la representación de TanguyMaldoror reaparece personificado, consintiendo placidamente su desangre [fig. 14]. El surrealismo, fustigado por Sade y Lautréamont, encendió este tipo de vampirismo que es a un tiempo placer incontrolable y prefiguración de muerte.

49 TORCZYNER, Harry, op. cit., pp. 9-20. También, se recomienda el magnífico libro de, GABLIK, Suzi, op. cit., pp. 44-48.

50 HUBERT, Renée Riese, op. cit., p. 205. 


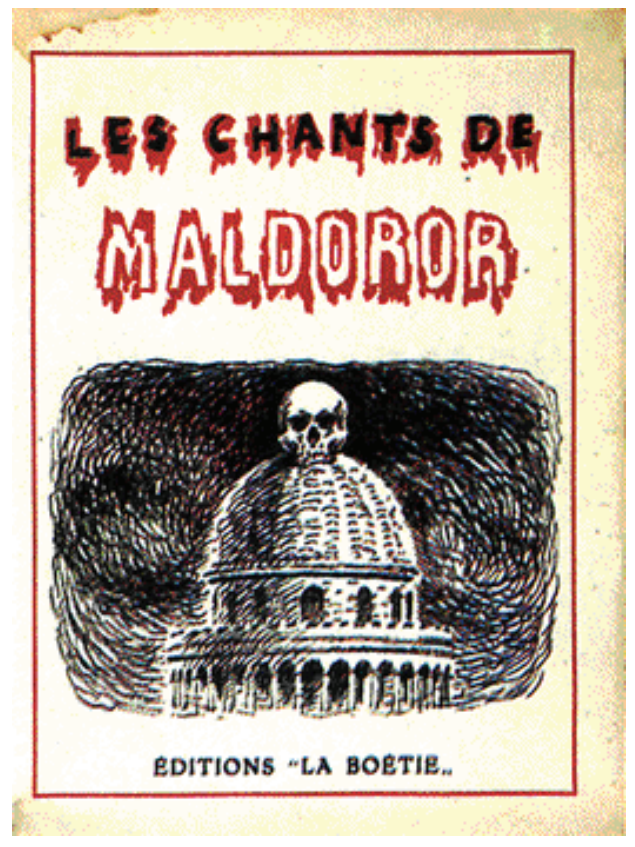

Fig. 13: René Magritte. Ilustración para Les Chants de Maldoror: portada. 1948. Col. Particular, (LAUTRÉAMONT, Comte de, Les Chants de Maldoror, dessins de René Magritte, Brussels, Editions de la Boétie. 1948, p. 0).

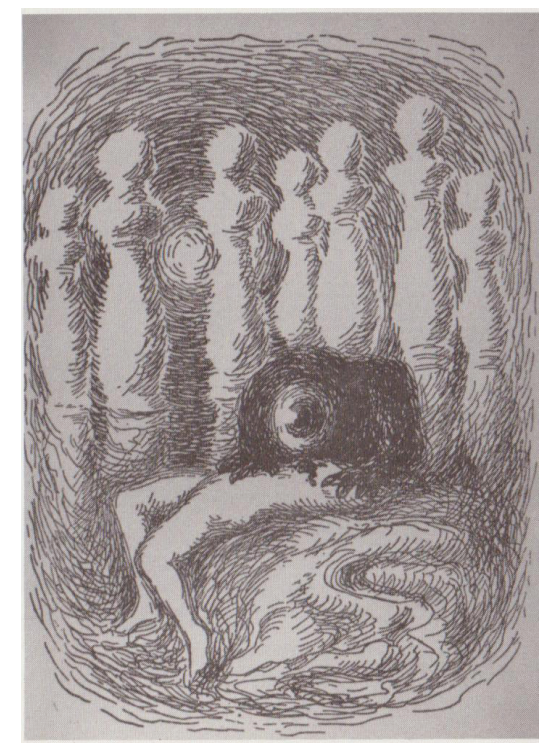

Fig. 14: René Magritte. Ilustración para Les Chants de Maldoror: pasaje de vampirismo arácnido. 1948. Col. Particular. (HUBERT, Reneé Riese, Surrealism and the book, Berkeley, University of California Press, 1988, p. 200). 


\section{Conclusiones}

Después de este breve recorrido, parece evidente constatar que el retrato de Maldoror haya copado gran parte del imaginario surrealista entre 1934 y 1948. Lautréamont era considerado un aparecido para los surrealistas, algo que pudiera haber condicionado esa tendencia a lo fantasmagórico en los retratos de Maldoror. De todos modos, sabemos que el héroe -al igual que su creador- es un ente sin rostro, por lo que, de manera obligada, los artistas apelan a su imaginación para crear una retratística fantástica y personalizada. Quizás, en la variedad resida la verdadera riqueza de estos retratos, siempre distintos, y alterados a través de pócimas paranoico-críticas, juegos automatistas, y demás recursos surrealistas ${ }^{51}$.

El rostro de Maldoror, y por extensión todo lo relacionado con Lautréamont y su Les Chants de Maldoror, ha sido una de las obsesiones más intensas y detectables del primer surrealismo. Su presencia ha sido una constante que se ha dejado ver en infinitud de obras mayores. L'image d'Isidore Ducasse (1933) de Man Ray, La Machine à coudre èlectro-sexuelle (1934) de Óscar Domínguez, La métamorphose (1936) de André Masson, el Recontre Fortuite from Jean Saus Terre Nettoye par le Vide (1940) de Kurt Seligmann, el Cannibalisme de la mante religieuse de Lautréamont, o el Homenaje a Lautréamont (1945) de Dalí, son sintomáticas de este empeño.

Parece, pues, ineludible verificar ese entrecruzamiento entre lo leíble de la poética lautreamontiana y lo visible de la plástica surrealista. Como una traslación etílica, el emblema verbal del Conde ha germinado - cincuenta años después- en una suerte de ricas emulsiones pictóricas ${ }^{52}$. Estas han resultado ser el principal alimento del total orbe surrealista. Sabemos que el dardo envenenado de Ducasse ha alcanzado a gran parte de los creadores de aquel París ansiado de nuevas propuestas. Esto se ha dejado entrever, de manera clara, a través de la recepción de su prolífica imaginería; una recepción tan variopinta y plural como singularizada en sus planteamientos.

Fuera de los marcos temporales de este artículo, Lautréamont y su héroe, serán representados por los principales artistas de vanguardia, pero eso es materia de otro estudio $^{53}$. Los rostros de Maldoror y su creador siguen siendo, aun hoy, una fecunda fuente de inspiración para muchos artistas neosurrealistas. Valga como ejemplo, y amodo de cierre, el estupendo Hommage à Lautréamont (1990) de Hugues Gillet.

51 BRADLEY, Fiona, Surrealismo, Madrid, Ediciones Encuentro, 1999, p. 8.

52 MOURE PAZOS, Iván, El bestiario...op. cit, p. 312. "No podemos olvidar que Lautréamont sobrevuela el impresionismo, el simbolismo, el fauvismo, el cubismo, el futurismo e incluso el dadaísmo, para eclosionar en aquel primer surrealismo que lo vindicó como deidad". El origen de esta obsesión pudiera fecharse en torno a 1919, cuando Andre Breton copia a mano de la $B n F$ la obra de Lautréamont. Para más información consultar: FERNÁNDEZ URTASUN, Rosa, "La poética de Lautréamont y la escritura vanguardista" en Thélème. Revista complutense de estudios franceses, Madrid, núm. 14, 1999, p. 59; KRAUSS, Rosalind, El inconsciente ...op. cit., p. 55.

53 Para todo aquel interesado en el tema de Lautréamont y las artes visuales allende el surrealismo, se recomienda el texto de DURAND-DESSERT, Liliane, "Lautréamont et les arts visuels (1870-1998)" en Cahiers Lautréamont, Montréal, livraisons XLVII-XLVIII, nos. 47-48, octobre 1998, pp. 81-161. Pena que tratándose de un texto que trabaja con imágenes, sean éstas inapreciables en tamaño y definición, algo que contrasta con la excelente calidad del artículo, casi libro. Tampoco desmerece, en este sentido, el escueto texto de GIL FARGAS, Gerard, "Arde el mar Dolor” en Revista Bacarola ...op. cit., pp. 238-241. Donde se desvelan los coqueteos de algunos cineastas con el mundo ducassiano. 